\title{
The kinetics of endotoxin and cytokines in dengue hemorrhagic fever
}

\author{
Sri Rezeki H Hadinegoro
}

\begin{abstract}
Abstrak
Endotoksin serum dapat ditemukan pada 63.3\% di antara 120 kasus demam berdarah dengue (DBD). Proporsi endotoksemia maupun kadar endotoksin lebih tinggi pada sindrom syok daripada kelompok non-syok (berturut turut 13.9 dan $4.3 \mathrm{pg} / \mathrm{ml}$, p=0,0008). Keadaan sindrom syok pada DBD mempunyai risiko 3 kali lebih besar untuk menderita endotoksemia daripada kelompok non-syok (OR 3.0; interval kepercayaan 95\% 1.29-7.05) Endotoksin meningkat pada saat terjadi syok dan menurun kembali apabila syok telah teratasi. Risiko endotoksemia untuk menjadi infeksi dengue berat 5.8 kali lebih tinggi daripada kelompok tanpa endotoksemia (OR 5.5; interval kepercayaan 95\% 1.72-21.74). Tunor nekrosis faktor alfa dan interleukin-6 merupakan jenis sitokin yang ditemukan pada kasus DBD. Sebagai mediator pro-inflamasi TNF- $\alpha$ meningkat pada fase awal penyakit dan menurun kembali pada fase penyembuhan, sedangkan IL-6 dapat ditemukan di dalam sirkulasi pada awal fase penyembuhan sebagai mekanisme umpan balik atas peningkatan endotoksin dan $T N F-\alpha$.
\end{abstract}

\begin{abstract}
Endotoxin was detected in $63 \%$ among 120 dengue hemorrhagic fever (DHF) cases. The proportion of endotoxemia in shock group were higher than that non-shock as well as serum endotoxin level ( 13.9 and $4.3 \mathrm{pg} / \mathrm{ml}$ respectively, $p=0.0008$ ). Shock group has 3.0 times risk to have endotoxemia than that non-shock DHF group (OR 3.0; 1.29-7.05 95\% CI). Serum endotoxin concentration increased at the time of shock and decrease after shock recovered. Patients with endotoxemia has 5.8 times higher risk to develop severe dengue infection compared to non-endotoxemia group (OR 5.5; 1.72-21.74 95\% CI). Pre-inflammatory mediator TNF- $\alpha$ can be detected at the beginning of the disease and disappeared on convalescence stage, while IL-6 titer increased at the early convalescence phase as a feed back mechanism to endotoxin and TNF- $\alpha$.
\end{abstract}

Keywords: endotoxin, cytokines, dengue hemorrhagic fever

Dengue hemorrhagic fever (DHF) has been already known in Indonesia since two decades ago. As an endemic disease, dengue infection did not appear as a health problem at that time, but during the last 20 years many fatal cases were reported. ${ }^{1}$ Government's effort has been succesful to decrease the mortality rate; however, this disease through national health program, the mortality rate in several hospitals is still high. ${ }^{2-5}$ Better case management is needed, especially for shock syndrome.

Shock is the primary evidence in severe DHF, other vital organ involvement are secondary to shock. ${ }^{6}$ Hospital data show that mortality of shock cases is 3 to 10 times compared to non shock group. On the other hand, the severity of shock syndrome depends on the pathogenesis of the disease. 7 A group of scientist hypothesized that four pathways were activated during

Department of Child Health Faculty of Medicine University of Indonesia/Dr. Cipto Mangunkusumo Hospital, Jakarta, Indonesia the course of illness, i.e. complement, endothel, platelets, and cytokine pathway. These four pathways work synergistically. Complement and cytokines promote hypovolemic shock via anaphylatoxin substance ( $\mathrm{C} 3 \mathrm{a}, \mathrm{C} 5 \mathrm{a})$ release. $^{8}$ Cytokine as pre-inflammatory mediators of infectious agents seems to play a role in the pathogenesis of $\mathrm{DHF}^{9}$ 'The cytokine production is needed for natural and specific host immunity against infection. Contrarily, overproduction of cytokine by monocytes as the subsequent target organ in DHF induced cell damage.

Other effects of increased vascular permeability and shock are ischemia, reperfusion, and damage of intestinal mucosa integrity. ${ }^{10,11}$ These conditions promote bacterial/endotoxin translocation from intestinal Jumen to lymphatic duct and finally to the blood circulation. ${ }^{12,13}$ Endotoxin as an outer capsul of Gram negative bacteria has a biological activity to stimulate cardiovascular and respiratory system, complement, coagulation, metabolic, and cytokine cascades. ${ }^{14}$ Tumor necrosis factor- $\alpha$, interleukin-1, and inter- 
leukin- 6 are the most common cytokines that are activated by endotoxemia. ${ }^{15}$ Finally, endotoxemia will induce severe shock and hemorrhage in DHF cases.

Concerning the matter mentioned above, the roles of endotoxin and cytokine in DHF should be further studied.

\section{METHODS}

A prospective, observational study was conducted on $120 \mathrm{DHF}$ patients who were hospitalized in Dr. Cipto Mangunkusumo Hospital Jakarta, during 26 month period, from February 1993 through April 1995. The diagnosis was established according to WHO diagnostic criteria, confirmed by hemaglutination inhibition and dengue blot IgM/IgG serological test. Intended sample was taken from the DHF cases who fulfilled the inclusions criteria. The inclusion criterias were grade I, II, III, and IV of DHF cases, no signs and symptoms of bacterial infections, and all patients signed the informed consent.

\section{Clinical and laboratory evaluation}

Clinical data of DHF patients were recorded on admission. Clinical condition and laboratory examination were followed i.e. time of shock recovered, complication of shock (prolonged or recurrent shock), time of defervesence (fever ceased), and gastrointestinal bleeding. Hemoglobin content, hematocrit value, WBC, differential count, and platelet count were examined at the Child Health Department Dr.Cipto Mangunkusumo hospital, while serum complement $\mathrm{C} 3, \mathrm{C} 4$, and fibrinogen titers were examined at the Clinical Pathology Department of the same hospital. Examination of hemoglobin content, hematocrit value, and platelet, count were repeated every 6 hours until the patients condition improved significantly.

\section{Limulus Amoebocyte Lysate (Endospecy) test}

Serum endotoxins were detected by chromogenic limulus test, i.e. limulus amoebocyte lysate (Endospecy) test made by Seigaku Kogyo Co.Ltd.Japan with endotoxin standard E.Coli ET.0111:B4. The purpose of pretreatment of serum specimen using new perchloric acid was to minimize the influence of endotoxin inhibitor. Besides endospecy test, an this study also used limulus toxicolor test. Endospecy and Toxicolor limulus test was used simultaneously to exclude the positive result by $\beta$-glucan as a component of mycosis, that could be detected by toxicolor test only.
All glasses, tubes, and pipettes were heated at $180{ }^{\circ} \mathrm{C}$ for 4 hours by autoclave to get pyrogen free, as well as the heparin solution and diluted water. Two milliliters of venous blood were/poured into the heparini-zed endotoxin free tube $30 \mathrm{IU} / \mathrm{ml}$ (made by Dalcon company), then centrifuged at $1000 \mathrm{xg}$ for 10 minutes. Afterwards, the procedure was done as followed,

$$
\begin{aligned}
& \text { Incubated at } 37^{\circ} \mathrm{C} \text { in } 5 \text { minutes } \\
& +50 \mathrm{Ul} 0.32 \mathrm{M} \text { perchloric acid } \\
& \text { Incubated at } 37^{\circ} \mathrm{C} \text { in } 10 \text { minutes } \\
& +100 \mathrm{Ul} 0.18 \mathrm{M} \mathrm{NaOH} \\
& 150 \mathrm{Ul} \text { of aliquot } \\
& ++50 \mathrm{Ul} 0.2 \mathrm{M} \text { Tris- } \mathrm{HCl} \text { buffer (pH8) } \\
& \text { Incubated at } 37^{\circ} \mathrm{C} \text { in } 30 \text { minutes } \\
& \text { Diazotiation by } 25 \% \text { acetic acid } \\
& \text { Read on spectrophotometer } \\
& \text { OD (optimal density) } 545 \mathrm{~nm} \\
& \text { (Ref. K.Inada) }
\end{aligned}
$$

Control positive and negative tests were needed for each 20 specimen in Endospecy and Toxicolor test, respectively. All examinations a were done in duplo.

\section{Cytokine Assay}

Cytokine was examined quantitatively by a two- step monoclonal antibody method, i.e enzyme linked immuno-sorbent assay (Elisa) method, made by Endogen Inc.Boston MA, USA, used for TNF- $\alpha$ detection; while detection of II-6 concentration was done by Genyme-kit, Boston MA, USA. The limits of detection of these assays was $3.0 \mathrm{pg} / \mathrm{ml}$. The principle of cytokine assay used was avidin-biotin amplifier in a two-step sandwich method, as described below :

1. Microplate of 96 wells covered by cy tokine specific monoclonal antibody (TNF- $\alpha v$ and IL-6). This antibody was called a primary antibody.

2. Put specimen into the wells of the microplate that had been covered by primary antibody.

3. Then, put secondary monoclonal antibody i.e. biotinylated anti-human cytokine (TNF- $\alpha$ or IL-6) to get the antigen-antibody complex.

4. Avidin enzym (HRP) which has a high afinity to biotin put thereafter to get the antigen-antibody enzyme complex.

5. Finally enzyme reaction was added by colored reagents, changes of color were calculated by spectrophotometer. 
Endotoxin, TNF- $\alpha$, and IL- 6 assays were examined at the Department of Bacteriology Iwate Medical University, Morioka, Japan. Examination of serum endotoxin, TNF- $\alpha$, and IL-6 titers were done every day during hospitalization ( 3 to 5 days). The serum specimen were collected and stored at $-70^{\circ} \mathrm{C}$ before the examination was done.

\section{Serological test}

Serological hemagglutination inhibition (HI) and Dengue Blot IgM and IgG tests were taken admission and on discharge from hospital. Serological hemagglutination inhibition were examined at the laboratory of National Institute of Health Ministry of Health of Indonesia, while Dengue Blot IgM and IgG tests were done at the Prodia Laboratory, Jakarta.

\section{Research design}

The designs of this study were (1) cross sectional to get the clinical characteristics and laboratory data, and the endotoxemia prevalence. (2) Follow-up study to get the figure of endotoxin, TNF- $\alpha$, and IL-6 kinetics during the clinical course of the disease. The sample size was calculated for study on endotoxemia titer in each stadium of the illness by estimation of the endotoxemia proportion of non-shock DHF cases of $27 \%$, Odds ratio $3.0, \alpha$ value 0.05 , and $\beta 0.20$. The calculated sample size was 64 .

\section{Statistics and analysis}

Data were recorded in a the research form and were analyzed by EPI Info 6 and SPSS programs. Odds ratio was calculated for the different endotoxemia prevalence with $95 \%$ confidence intervals, $x^{2}$ and $p$ value. $T$ test was used for the difference of the two independent means. For proportion $x^{2}$ or Fisher Exact test were used. Statistically significance difference was $\mathrm{p}<0,05$.

\section{RESULTS}

\section{Subject characteristics}

The mean age of the study subjects was 6.1 (SD 3.0) years, the youngest was 8 months and the oldest was 13 years old. There were $45.8 \%$ females and $54.2 \%$ males. Among 120 patients, $19(15.8 \%)$ were undernourished $(<10$ percentile of NCHS).
Table 1. Subject characteristics

\begin{tabular}{crr}
\hline & n (total $=120)$ & $\%$ \\
\hline Age group (year) & & \\
$<1$ & 2 & 1.7 \\
$1-4$ & 53 & 44.2 \\
$5-9$ & 53 & 44.2 \\
$>10$ & 12 & 9.9 \\
Sex & & \\
male & 55 & 45.8 \\
$\quad$ female & 65 & 54.2 \\
Nutritional status & & \\
$\quad$ well-nourished & 101 & 84.2 \\
undernourished & 19 & 15.8 \\
\hline
\end{tabular}

Duration of fever before admission was 2-6 days. Symptoms of vomiting, diarrhea, and convulsion were common findings in young children, while abdominal pain was commonly found in older children. Sixty four (53.3\%) cases had evidence of shock. Seventy-eight percent of cases showed petechiae and $14 \%$ among 120 cases had gastrointestinal bleeding.

Table 2. Clinical manifestations on admission

\begin{tabular}{lrr}
\hline Clinical pictures & $\mathrm{n}($ Total $=120)$ & $\%$ \\
\hline Duration of fever (day) & & \\
2 & 12 & 10.0 \\
3 & 38 & 31.7 \\
4 & 41 & 34.2 \\
5 & 3 & 2.5 \\
6 & 3 & 2.5 \\
Shock & 64 & 53.3 \\
Hepatomegaly & 87 & 72.5 \\
Other signs \& symptoms & & \\
Vomiting & 42 & 35,0 \\
Diarrhoea & 28 & 23.3 \\
Epigastric Pain & 73 & 61.5 \\
Convulsion & 10 & 8.3 \\
Bleeding manifestations & & \\
Positive Tourniquette Test & 77 & 64.2 \\
Petechiae & 94 & 78.3 \\
Epistaxis & 21 & 17.5 \\
Hematemesis & 17 & 15.8 \\
Melena & 19 & \\
\end{tabular}

\section{Endotoxemia}

The endotoxin mean titer in DHF was deficted on Table 3. Significant difference between endotoxin titers in shock and nonshock DHF cases was indicated $(\mathrm{p}=0.0008)$. 
Table 3. Endotoxin titre in DHF shock and non-shock

\begin{tabular}{lcc}
\hline Grade of Illness & Cases & Mean Rank $(\mathrm{pg} / \mathrm{ml})$ \\
\hline Non-shock & 56 & 4.3 \\
Shock & 64 & 13.9 \\
\hline Total & 120 & 5,4 \\
\hline
\end{tabular}

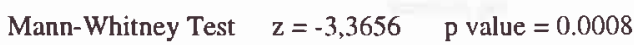

The endotoxin mean titer in the non-shock group was $4.3 \mathrm{pg} / \mathrm{ml}$, below the cut off point $(9.8 \mathrm{pg} / \mathrm{ml})$ while in the shock group was three times higher than that in the non-shock group $(13.9 \mathrm{pg} / \mathrm{ml})$. In this study $76(63.3 \%)$ among 120 DHF cases suffered from endotoxemia (Table 4); the proportion of endotoxemia in shock group was higher than that in non-shock group. The risk of shock group for having endotoxemia was three times compared to that of non-shock group (Odds ratio $3.0,1.29-7.05$ of $95 \%$ confidence interval, $\mathrm{p}$ value was 0.008 ).

Table 4. Risk factors of endotoxemia in DHF

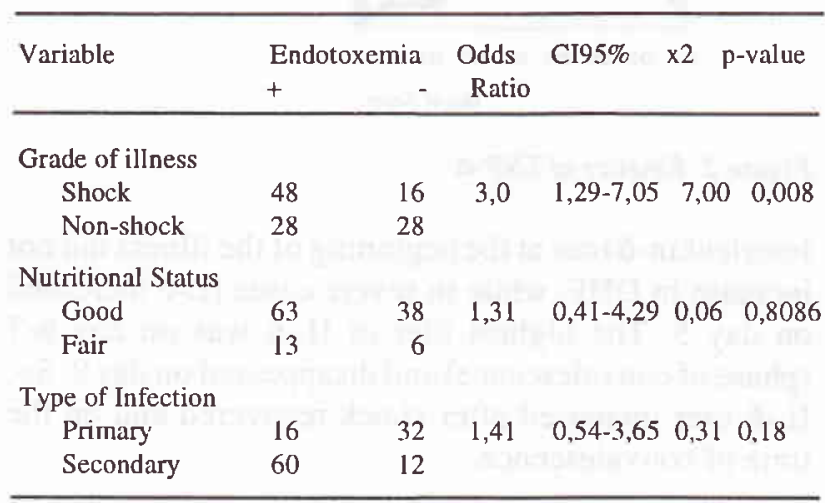

The decrease of $\mathrm{C} 3$ and $\mathrm{C} 4$ concentration was clearly shown in endotoxemia group. These findings support the high level of hemoconcentration in endotoxemia group. Hemoconcentration in endotoxemia group was above $20 \%$, indicating severe plasma leakage. Consumption of fibrinogen in endotoxemia was higher than non-endotoxemia group, while the platelet count was almost similar between the two groups.
Table 5. Laboratory findings in endotoxaemia

\begin{tabular}{lll}
\hline & $\begin{array}{l}\text { Endotoxemia }(+) \\
\text { Mean }(95 \% \mathrm{Cl})\end{array}$ & $\begin{array}{l}\text { Endotoxemia }(-) \\
\text { Mean }(95 \% \mathrm{CI})\end{array}$ \\
\hline $\begin{array}{l}\text { Platelet }(/ \mu \mathrm{l}) \\
\text { Hemoconcentra- }\end{array}$ & $89500(15000-348000)$ & $96500(12000-323000)$ \\
$\quad$ tion $(\%)$ & $24.6(5.7-67.2)$ & $15.7(2.5-50.0)$ \\
C3 $(\mathrm{mg} / \mathrm{dl})$ & $20.6(0.42 .2)$ & $34.7(13.1-56.3)$ \\
C4 $(\mathrm{mg} / \mathrm{dl})$ & $17.1(2.8-31.4)$ & $23.0(9.3-36.7)$ \\
Fibrinogen $(\mathrm{mg} / \mathrm{dl})$ & $95.5(5.2-185.8)$ & $139(52.7-225.3)$ \\
\hline
\end{tabular}

\section{Cytokine assay}

Cytokine examinations i.e. TNF- $\alpha$ and IL- 6 titer as shown in Table 6. There was no significant difference between TNF- $\alpha$ and IL- 6 mean titer in endotoxemia or without endotoxemia group.

Table 6. TNF- $\alpha$ and IL- 6 titer in endotoxemia

\begin{tabular}{lcccc}
\hline $\begin{array}{l}\text { Cytokine } \\
(\text { Mean rank } \\
\mathrm{pg} / \mathrm{ml})\end{array}$ & $\begin{array}{c}\text { Endotoxemia } \\
(+)\end{array}$ & $\begin{array}{c}\text { Endotoxemia } \\
(-)\end{array}$ & $\mathrm{z}$ & $\mathrm{p}^{*}$ \\
\hline TNF- $\alpha$ & 58.1 & 50.7 & & \\
& $\mathrm{n}=72$ & $\mathrm{n}=38$ & -1.1535 & 0.2487 \\
IL-6 & 54.5 & 50.0 & & \\
& $\mathrm{n}=69$ & $\mathrm{n}=36$ & -0.7192 & 0.4720 \\
& & & & \\
\hline
\end{tabular}

*Mann-Whitney Rank Test

The follow-up study showed that the duration of fever, evidence of shock, and gastrointestinal bleeding during hospitalization were the important factors of prognosis. The mean of the duration of fever was 1.2 (SD 0.9) days, in shock group it was longer than in non-shock group. The mean of the duration of shock was 48.0 (SD 26.6) minutes, while in survivors cases of prolonged and recurrent shock it was 91.4 (SD 26.3) minutes. Attention should be paid to DHF cases who had gastrointestinal bleeding on admission, since $73 \%$ among them continued bleeding during hospitalization. The mean of the duration of gastrointestinal bleeding was 2.1 (SD 1.0) days.

\section{Severe dengue infection}

Severe dengue hemorrhagic fever (shock group and their complications, i.e. prolonged shock, recurrent shock, gastrointestinal bleeding, and encephalopathy) occurred in $32(26,7 \%)$ among 120 studied subjects. 
The median endotoxin titer in severe DHF was higher than that in DHF, especially in those with prolonged shock, recurrent shock, or gastrointestinal haemorrhage. Median endotoxin titer in dengue encephalopathy was below the cut off point endotoxin level. The cause of death of 4 among 9 death patients were prolonged and recurrent shock which have higher endotoxin titer compared to other 5 death patients which were caused by gastrointestinal bleeding and encephalopathy.

Table 7. Endotoxin titer in severe DHF

\begin{tabular}{lrrc}
\hline & \multirow{2}{*}{$\begin{array}{c}\text { Cases } \\
(\mathrm{n}=32)\end{array}$} & \multicolumn{2}{c}{ Endotoxin $(\mathrm{pg} / \mathrm{ml})$} \\
\cline { 3 - 4 } & & Median & Range \\
\hline Prolonged Shock & 7 & 22.6 & $2.3-180$ \\
Recurrent Shock & 15 & 24.1 & $1.6-10$ \\
GI Bleeding & 16 & 10.7 & $0-180$ \\
Encephalopathy & 6 & 4.7 & $0-79$ \\
Death & 9 & 17.1 & $0-180$ \\
\hline
\end{tabular}

Endotoxemia as a single dependent variable proved to be a predictor of severe DHFas shown in Table 8, with an Odds ratio of 5,8 (95\% confidence intervals: 1,721,7 , p value 0,0019 ).

Table 8. Proportion of severe dengue infection

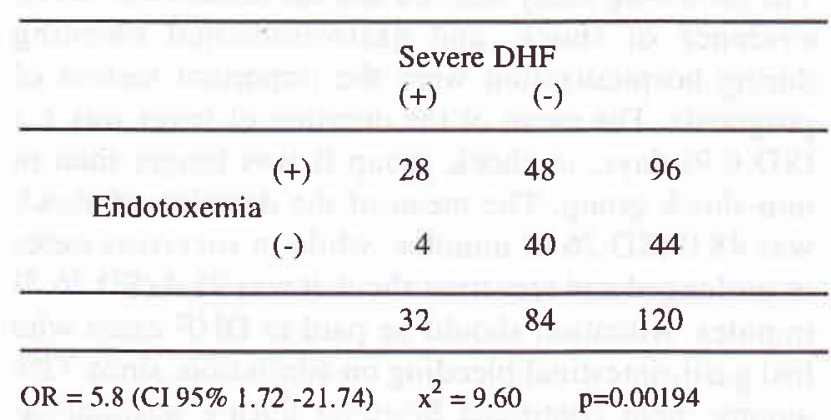

Endotoxin appeared in the serum on day 3 of illness, reaching the peak level on day 6 (shock phase), and disappeared after day 7 (convalescence phase). Compared to the more moderate DHF cases, endotoxin in severe DHF appeared earlier and had a higher level.

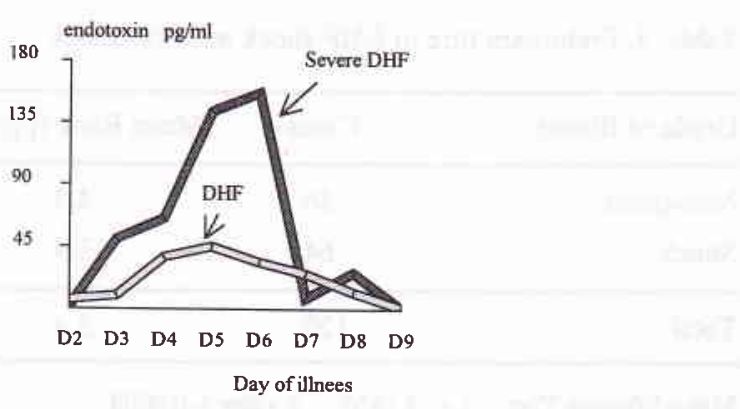

Figure 1. Kinetics of endotoxemia

Figure of TNF- $\alpha$ in DHF cases during the course of illness was quite different with the endotoxin figure. TNF- $\alpha$ increased on day 2 to 3 , earlier than endotoxin. In severe DHF cases, TNF- $\alpha$ titer increased quickly when entered shock phase (day3) and were still in high level during shock phase (day 3-5), finally decreased on the day of convalescence. In DHF cases, TNF- $\alpha$ titer increased on day 4 until day 9 , lower than in severe DHF stayed longer in the serum.



Figure 2. Kinetics of $T N F-\alpha$

Interleukin- 6 titer at the beginning of the illness did not increase in DHF, while in severe cases IL-6 increased on day 5. The highest titer of IL-6 was on day 6-7 (phase of convalescence) and disappeared on day 9. So, IL-6 titer increased after shock recovered and on the time of convalescence.

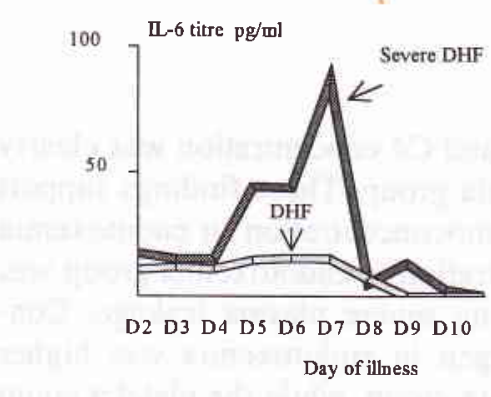

Figure 3. Kinetics of Il-6 
As a pre-inflammatory mediator in infections, TNF- $\alpha$ titer in DHF increased at the begining of the course of illness and decreased immediately after the infection ceased. This picture was more clearly seen in severe DHF than that in DHF group. In DHF group as a result of immune response, high TNF- $\alpha$ level was still seen in the convalescence phase. This study proved that TNF- $\alpha$ titer did not correlate significantly with endotoxemia; however TNF- $\alpha$ and endotoxin have quite similar kinetic with the pathogenesis and the course of illness of this disease. Another cytokine detected in DHF was IL-6. Interleukin-6 titer in DHF correlated significantly with endotoxin and TNF- $\alpha$ titer. This correlation was shown in the follow-up study on the IL-6 kinetic level during hospitalization. In DHF group, IL-6 did not reach cut-off point either following endotoxin or TNF- $\alpha$ level. This figure was quite different compared to that of severe DHF group. In severe DHF group, endotoxin as well as TNF- $\alpha$ reached high level, followed by increased IL- 6 titer. As there was statistically significant positive correlation between IL-6 titer and endotoxemia, it was suggested that the increased $\Pi \mathrm{L}-6$ in severe DHF group was due to a negative feed back mechanism of endotoxin and TNF$\alpha$ production.

\section{DISCUSSION}

In the last five years many endotoxin studies were done in animal experiments, unfortunately there was no available animal study in DHF. ${ }^{10-12}$ This study was conducted to explore the roles of endotoxin in DHF by systematic clinical and laboratory observation. Kinetics of endotoxin are characterized as species specific in animal studies. Biological respons and immune status in human are the most important parts for endotoxin elimination. 15

Endotoxin is a polysaccharide component of outer capsul Gram negative bacteria. In general, there is no endotoxemia in viral infection. Morales et al proved that endotoxin could reach the circulation due to ischaemia or histological intestinal mucosa damage in post haemorrhagic shock in animal study. ${ }^{10}$ Several factors, i.e., intestinal trauma, burn, shock, severe malnutrition, and prolonged parenteral nutrition also cause intestinal ischemia to promote bacterial/ endotoxin translocation from gut flora to blood circulation. This study supported the hypothesis of bacterial/ endotoxin translocation in DHF, as shown, endotoxin titer increased three times in shock compared to non-shock group, i.e., $18.9 \mathrm{pg} / \mathrm{ml}$ and $4.3 \mathrm{pg} / \mathrm{ml}$ respectively. Non-shock group DHF never reached cut-off point at $9.8 \mathrm{pg} / \mathrm{ml}$ during hospitalization.
The prevalence of endotoxemia in DHF in this study was $63,3 \%$, it was higher in shock compared to nonshock group. Usawattanakul from Thailand reported that endotoxemia occured in $43.5 \%$ among 57 DHF patient, the prevalence was higher in shock compared to non-shock group. ${ }^{16}$ Limulus tests was used in this two studies were different. This study used Limulus Amoebocyte Lysate (LAL) test which is more sensitive than gelatin limulus test (semiquantitative) used by Usa. Plasma endotoxin concentration is not quite similar to endotoxin tissue concentration. Some plasma protein such as transferrin, HDL (high density lipoprotein), and other acute phase protein will bind endotoxin in the circulation. New-PCA (perchloric acid) which contain hydroxy sodium to break the connection between endotoxin and plasma protein, to get the true plasma endotoxin concentration. ${ }^{17} \mathrm{By}$ new procedure for pre-treatment, LAL test is more accurate than gelatin limulus test.

DHF cases can be divided into by shock and non-shock cases. The two groups have different prognosis. In this study, the risk to have endotoxemia in shock group was three times higher than non-shock group (OR 3.0 95\%CI 1.29-7.05). This result support Nimmannitya's statement that shock in severe DHF is primary evidence and other organ disturbance is secondary to shock. ${ }^{6}$ Hypovolemic shock in DHF is due to complement activation by release of anaphylatoxin mediators (C3a, C5a). Malasit reported that biological effects of C5a are to increase capillary permeability, increase chemotactic effect of neutrophils and monocytes, stimulation of monocytes to cytokines release particularly TNF, IL-1, and Il-6, degranulation of mast cells followed by histamin release, stimulate prostaglandin and free radical oxygen. ${ }^{8}$ Complement concentration in this study was decrease due to activated classic and alternative pathways as reported by Malasit. ${ }^{8}$ She reported her study on complement system five years later, proved that in DHF, SC5b-9 was activated. In conclusion, complement activation is the most important pathway in the pathogenesis of DHF. Endotoxemia group has low C3 concentration compared to non-endotoxemia group, but this difference did not occur in $\mathrm{C} 4$ concentration. In the early stage of the disease $\mathrm{C} 3$ and $\mathrm{C} 4$ concentration decreased due to classic and alternative pathways activation by either dengue virus or immune complex; after endotoxin entered the circulation C3 was decreased by classical pathway activation due to endotoxin release.

Endotoxin concentration was detected on day three of illness, continued to have high concentration on day 4 , 
5 , and 6 , and reached the highest concentration on day 5 , and declined on day 7 of illness. This kinetics followed DHF pathogenesis, ie. febrile phase on day $1-3$, shock phase on day 3-7, and convalescence phase after day 7 of illness. So, endotoxin increased in febrile phase and reached the highest concentration on shock phase, and endotoxin concentration as well as body temperature decreased on convalescence phase. This result pointed out that temperature was a good clinical parameter for follow-up during the course of illness.

Evidence of endotoxemia correlated with gastrointestinal hemorrhage. Endotoxin concentration was higher DHF in which gastrointestinal haemorrhage occured more than 2 days. Disturbances of coagulation system and decrease of platelet are the important causes of gastrointestinal haemorrhage in DHF. In this study, no difference was observed between platelet concentration in endotoxemia or no endotoxin group; while fibrinogen concentration showed significance difference between the two groups $(\mathrm{p}=0,005)$. The cause of hemorrhage in DHF is multifactorial, as reported by Isarangkura and Funahara. ${ }^{18,19}$ Bhamarapravati reported a massive haemorrhage of renal cortical tissue (Waterhouse-Friederichsen syndrome, a picture of severe kidney damage in septic/ endotoxic shock) in the autopsy study, it is suggested that endotoxin played a role in fatal severe dengue infection cases. ${ }^{20}$

On the second day of illness $65.5 \%$ of cases have increased TNF- $\alpha$ concentration, at $29.5 \mathrm{pg} / \mathrm{ml}$. Tumor necrosis factor as a pro-inflammatory mediator produced by activated macrophage as a target organ of dengue infection. ${ }^{7,21}$ Increased TNF- $\alpha$ concentration occured either in shock or non-shock group. In the severe DHF case (profound shock called DHF grade IV) TNF- $\alpha$ titer was increased until the inflammation process ceased. The concequences of increased TNF- $\alpha$ titer were increased capillary endothel permeability, decreased tissue oxygen perfusion, and finally patients died due to multiorgan failure. ${ }^{22}$

Serum TNF- $\alpha$ concentration increased on the second day while endotoxin increased on the next day, and serum TNF- $\alpha$ concentration reached highest concentration on fourth day of illness, earlier than endotoxemia reached the highest concentration. It is suggested TNF- $\alpha$ has important role since the beginning of the illness without influence of endotoxin stimulation. This result supported the opinion that production of cytokine occured at the beginning of the illness stimulated by immune complex to macrophage.
Cytokine activation stimulated through cytokine network, as well as TNF- $\alpha$ stimulated interferron, IL-1, IL-6, or TNF- $\alpha$ (auto-induction cycle). ${ }^{23}$ In the preliminary study, IL-1 as a specific protein or as an acute inflammatory mediator could not be detected in DHF patients. Hanley et al studied 56 children with DHF grade I to IV. ${ }^{24} \mathrm{He}$ found TNF- $\alpha$ and IL- 6 at the beginning of illness and disappeared on day 5 of illness. At the same time TNF- $\alpha$ and IL- 6 can be detected in the urine due to elimination of these cytokine via kidney. Interleukin-6, also called as interferon-b, is a mediator which stimulates growth factor and $B$ lymphocyte differentiation, also give a negative feed back to TNF- $\alpha$ and IL-1. The biological function of IL-6 is stimulating hepatocyte produce acute phase protein and IL- 6 called as anti-inflammatory mediator. ${ }^{22}$ In viral infection, the function of IL- 6 was against virus activation via RNA and protein synthesis non-specific mechanism. In this study IL-6 titer increased at median titer $7.8 \mathrm{pg} / \mathrm{ml}$, in shock group IL-6 concentration was higher than non-shock group. There was positive relation between endotoxin and IL-6 levels. Increased IL-6 titer in shock group was due to negatived feed back mechanism to endotoxemia via TNF- $\alpha$ stimuli by blockade endotoxin-induced IL-1, TNF- $\alpha$ and IL-6. IL-6 increased slowly until day 7 of illness then decreased gradually. This study showed positive correlation between IL-6 and endotoxin as well as IL- 6 and TNF- $\alpha$. So, the aim of increasing of IL- 6 concentration is to reduce negative effect of TNF$\alpha$ and endotoxin. Examination of cytokine serum concentration at one time does not give a true value, because cytokines have short half life and will be eliminated via kidney immediately. ${ }^{24}$ Serial examination of cytokine serum concentration will show the kinetics of the true value of cytokine. ${ }^{25}$

Our previous experience showed that about $1 / 3$ of DHF cases suffered from shock syndrome and $1 / 3$ of shock cases were supposed to have recurrent \& prolonged shock, as well as massive gastrointestinal bleeding. ${ }^{5}$ Other complication ie. encephalopathy occured only in $5-7 \%$ DHF cases. In this study, recurrent shock, prolonged shock, gastrointestinal bleeding more than 2 days, encephalopathy, and all death cases, were all found in severe dengue infection. The endotoxin titer of severe DHF was $20.9 \mathrm{pg} / \mathrm{ml}$, almost four time higher than DHF (5.4 pg/ml). Endotoxin titer increased at the time of shock and very high titer showed in severe dengue infection. The risk to develop severe DHF in endotoxemia group was 5,8 times higher than that in non endotoxemia cases. 


\section{CONCLUSIONS}

Endotoxemia occurred in dengue hemorrhagic fever cases $(63,3 \%)$, in shock group $(75 \%)$ as well as in non-shock group (50\%); endotoxin titer in shock group $(13,9 \mathrm{pg} / \mathrm{ml})$ was significantly higher than that in nonshock group $(4,3 \mathrm{pg} / \mathrm{ml})$. The risk to develop endotoxemia in shock group was three times higher than that in non-shock DHF group. TNF- $\alpha$ level increased during the early course of illness and the kinetics were similar with the pathogenesis of the disease. In DHF, no correlation was found between increased TNF- $\alpha$ titer and endotoxin titer. Endotoxin titer in DHF has a positive relation with hematocrit as well as with IL-6 titer. On the other hand, IL- 6 titer had a positive relation with TNF- $\alpha$ titer. It is suggested that increased IL-6 titer related with feed back mechanism of increased endotoxin and TNF- $\alpha$ titer. The laboratory parameters i.e. platelet count, $\mathrm{C} 3, \mathrm{C} 4$, and fibrinogen titer in endotoxemia DHF cases were lower than those in non endotoxemia cases while the hematocrit titer was higher. The risk to develop a severe course of illness in endotoxemia DHF cases was 5.8 times higher than that in non endotoxemia cases.

\section{Acknowledgments}

I thank Prof. Masao Yoshida and Dr. Katsuya Inada PhD from Department of Bacteriology Iwate University Morioka Japan, for their support and guidance during my endotoxin and cytokine assay study. Also thanks to Dr. Riady Wirawan for helping with the complement and fibrinogen assays, Drh. Suharyono Wuryadi MPH for the hemagglutination inhibition serological dengue test, and Prodia Laboratory Jakarta for IgM and IgG dengue antibody examination.

\section{REFERENCES}

1. Sumarmo. Demam berdarah (Dengue) pada anak. Tjokronegoro A, ed. Jakarta, UI Press 1983.

2. Suroso T. Perkembangan demam berdarah dengue di Indonesia. Disampaikan pada Seminar Demam Berdarah Dengue. Jakarta, Departemen Kesehatan 8 Juni 1991.

3. Azhali MS. Demam berdarah dengue: pengalaman di Bagian Ilmu Kesehatan Anak RS Hasan Sadikin Bandung. Cermin Dunia Kedok Terapi. 1992; 81: 62-5.

4. Sachro ADB. Demam berdarah dengue: pengalaman di Bagian Ilmu Kesehatan Anak RS Karyadi Semarang. Cermin Dunia Kedok 1992; 81: 66-9.

5. Hadinegoro SR, Nathin AN. The changing pattern of clinical manifestations in dengue haemorrhagic fever: a ten-year observations. Disampaikan pada The International Symposium on Dengue Fever \& Dengue Haemorrhagic Fever. Bangkok, 1-3 Oktober 1990 .
6. Nimmannitya S. Clinical manifestations of dengue/dengue haemorrhagic fever. In: Thongchaeron P, ed. Monograph on dengue/dengue haemorrhagic fever. New Delhi: World Health Organization Regional Office for South-East Asia.Regional Publication 1993; 22: 48-54.

7. Kurane I, Rothman AL, Livingstone PG, Green S, Nimmannitya S, Innis FA. Immunopathologic mechanisms of dengue hemorrhagic fever and dengue shock syndrome. Arch Virol Suppl 1994; 9: 59-64.

8. Malasit P, Mongkolsapaya, Nimmannitya S, Suvatte S. Complement in dengue haemorrhagic fever/ dengue shock syndrome. In: Proc. the XIIIth International Congress for Tropical Medicine and Malaria. Pattaya, 29 November-4 December 1992.

9. Bhakdi S, Kazatchkine MD. Pathogenesis of dengue: an alternative hypothesis. The International Symposium on Dengue Fever \& Dengue Hemorrhagic Fever. Bangkok, 1-3 October 1990, 602-7.

10. Morales J, Kibsey P, Thomas PD, Poznansky MJ, Hamilton SM. The effect of ischemia and ischemia reperfusion on bacterial translocation, lipid peroxidation, and gut histology:study on hemorrhagic shock in pigs. J Trauma 1992; 33: 221-7.

11. Pasquale MD, Cipolle JH, Cerra FB. Bacterial translocation: myth versus reality. In: Reinhart K, Eyrich K, Sprung C, ed. Sepsis current perspective in pathophysiology and therapy; 1st.ed. Berlin, Budapest: Springer-Verlag, 1994: 84-106.

12. Deitch EA, Ma WJ, Ma L, Berg R, Specian RD. Endotoxininduced bacterial translocation: a study of mechanisms. Surgery 1989; 106: 292-300.

13. Edminton CE, Condon RE. Bacterial translocation. Surg Gynaec \& Obstet 1991; 173: 72-83.

14. Van Deventer SIH, Buller HR, Ten Cate JW, Sturk A, Pauw W. Endotoxaemia an early predictor on septicemia in febrile patients. Lancet 1988; 605-8.

15. Suffredini AF. Endotoxin administration to human. Dalam: Lamy M, Thijs L. eds. Mediators of sepsis. Berlin: Springer Verlag, 1992: 13-20.

16. Usawathanakul W, Nimmannitya S, Sarabenjawong K, Tharavanij S. Endotoxin and dengue haemorrhagic fever. Southeast Asian J Trop Med Pub Hlth 1987; 8:8-12.

17. Inada K, Endo S, Takahashi K, Suzuki M, Yoshida M. Establishment of a new perchloric acid treatment method to allow determination of the total endotoxin content in human plasma by the limulus test and clinical application. Microbiol Immunol 1991; 35: 303-14.

18. Isarangkura PB, Pongpanich B, Pintadit P, Planichyakam. Haemostatic dearrangement in dengue haemorrhagic fever. South East Asian J Trop Med Pub Hlth 1989; 20: 325-30.

19. Funahara Y, Hadinegoro SR, Nathin MA, Tamaela LA, Dharma S, Sumarmo. One of the cause of recurrent shock in DHF. The International on Dengue Fever/ Dengue Hemorrhagic Fever. Bangkok 1-3 October 1990.

20. Bhamarapravati N. Pathogenesis of dengue hemorrhagic fever. The International Symposium on Dengue and Dengue Hemorrhagic Fever. Bangkok, 1-3 October 1990.

21. Halstead SB. Pathophysiology and pathogenesis of dengue haemorrhagic fever. In: Thongchaeron, ed. Monograph on dengue/dengue haemorrhagic fever. New Delhi: World 
Health Organization Regional Office for South-East Asia.Regional Publication 1993; 22: 80-103.

22. Abbas AB, Lichtman AH, Pober JS, ed. Cytokines mediators. In: Cellular and molecular immunology. 1st ed. Philadelphia: WB Saunders 1991; 259-81.

23. Brenner MK. The cytokine network. In: Galvani DW, Cawley JC, ed. Cytokine therapy. 1st ed. Cambridge: Cambridge University Press 1992: 177-86.
24. Hanley PDO. Potential pathogenic roles of acute inflammatory cytokines and HLA status in DHF. Cermin Dunia Kedok 1992; 81: 17.2434.

25. Hadinegoro SR. Plasma endotoxin study on dengue hemorrhagic fever cases. In: Harun SR, Inada K. eds. Proceedings on one day seminar on endotoxin. Jakarta: University of Indonesia Press 1994: 27-34. 